\title{
CLOTHING AND FARMING ORIGINS: THE INDO-PACIFIC EVIDENCE
}

\author{
Ian Gilligan \\ School of Archaeology and Anthropology, Australian National University, Canberra 0200, Australia. Email: ian.g@bigpond.net.au \\ Keywords: origins of agriculture, textiles, eastern Asia, Oceania
}

\begin{abstract}
The development and dispersal of early farming practices dominates the post-glacial archaeological record in many parts of the world, including the Indo-Pacific region. The Papua New Guinean highlands have recently been added to a growing list of claimed independent centres for the transition to agriculture. In most areas, though, available data favour the diffusion of farming practices from a limited number of centres. Underpinning these debates is continuing uncertainty as to causal factors. Current concepts emphasise the role of environmental fluctuations and risk management strategies. However, problems and anomalies persist, including the failure of farming to appear in some regions, notably in Australia, and the dubious food value of some early domesticated species. A prevailing assumption about the transition is that it was predicated on acquisition of food for human consumption. A new model is outlined, positing a key role for the use of clothing. Evidence for an increasing utilisation of natural fibres to manufacture textiles is especially relevant. This model of early farming addresses outstanding theoretical and substantive issues. It also offers an innovative perspective on the relationship between farming and other post-glacial trends witnessed in many, though not all, human societies.
\end{abstract}

Cross-cultural studies show no significant differences in the security of the food supply between foragers and agriculturalists (Benyshek and Watson 2006), while evidence mounts that quality of life among some pre-industrial farming populations was reduced compared to that of foragers (e.g. Larsen 2006). For these and other reasons, the advent of farming has turned into a puzzle. Existing approaches maintain that it was an adaptive response to stress in the form of food shortages or population growth, or that it arose in more complex societies where there was greater use for surplus food production (e.g. Ingold 1984; Hayden 1990, 2003). On the other hand, a wide-ranging survey of proto-agricultural societies concludes that prevailing hypotheses, especially those implicating social causes, are "extremely improbable" (Keeley 1995:243266).

In response to this failure, there has been a move away from general - especially single-cause - theories. In- stead, differing combinations of factors are implicated in different regions (Smith 1995:208-214). One notion is that farming begins as a risk management strategy in times of environmental change, when seasonal resource availability becomes less predictable (Flannery 1986). Notwithstanding its shortcomings, the "risk minimization" model is currently in vogue, if only because it would "seem to be as good as any others" (Bellwood 2005:149). An inevitable result of recent trends is increasing debate concerning the definition of farming and, particularly, domestication (e.g. Winterhalder and Kennett 2006:2-4; Zeder 2006).

As Hayden (1990:32) observes:

Few topics in prehistory have engendered as much discussion and resulted in so few satisfying answers as the attempt to explain why hunter/gatherers began to cultivate plants and raise animals... Either the existing models are poorly conceived, cultures are more complex in this matter than archaeologists have assumed, or we have thus far overlooked a vital part of the puzzle.

The purpose here is two-fold: first, to raise questions concerning long-standing conventional assumptions about the priority of food and second, to show how clothingrelated issues add a useful (indeed, necessary) dimension to the discussion. The proposed model argues that an initial transition to farming occurred only where basic human needs included both food and clothing, and that it would not have occurred without the latter. Obviously, certain complexities in relation to both evidence and theory (for instance, the definition of domestication) cannot be covered here in any detail. Evidence is presented not to "prove" the validity of this position - hardly possible in this limited review - but to illustrate the potential value of this broader perspective.

\section{FOOD FOR THOUGHT}

Hayden highlights the social value of "luxury" products like woven fabrics and emphasises one major anomaly. In early farming contexts, most of the wild species brought under domestication were not especially useful for feeding people. This is indeed "puzzling" if provision of food for human consumption is the basis of the initial transition (Hayden 1990:32). Virtually all of the early plant and animal domesticates were multi-purpose resources, and many were essentially non-comestible (Table 1). Fibre 
Table 1. List of major domesticates (to mid-Holocene) and suggested relative importance of their uses when first domesticated. Scale: $\mathbf{0}$ = absent, 1 = minor, 2 = moderate, 3 = major. For plant taxa, $*=$ suggested role as feed for animals domesticated for fibres; for animal taxa, the redundant "animal food" column shows likely commensals in brackets; nomenclature for animal taxa follows Gentry et al. (2004).

\begin{tabular}{|c|c|c|c|c|}
\hline $\begin{array}{l}\text { Domesticated } \\
\text { species }\end{array}$ & $\begin{array}{l}\text { Human } \\
\text { food }\end{array}$ & $\begin{array}{l}\text { Animal } \\
\text { food }\end{array}$ & $\begin{array}{l}\text { Clothing- } \\
\text { related }\end{array}$ & $\begin{array}{l}\text { Other non- } \\
\text { comestible }\end{array}$ \\
\hline \multicolumn{5}{|l|}{ plants } \\
\hline einkorn wheat (Triticum sp.) & 1 & 3 & $1 *$ & 0 \\
\hline emmer wheat (Triticum sp.) & 3 & 2 & $1 *$ & 0 \\
\hline barley (Hordeum vulgare) & 1 & 3 & $1 *$ & 0 \\
\hline rye (Secale cereale) & 1 & 3 & $1 *$ & 0 \\
\hline legumes (Fabaceae sp.) & 2 & 3 & $1 *$ & 0 \\
\hline rice (Oryza sativa) & 3 & 1 & 1 & 1 \\
\hline millet (Panicum, Setaria sp.) & 1 & 3 & $1 *$ & 0 \\
\hline soybean (Glycine max) & 1 & 3 & $1 *$ & 0 \\
\hline flax (Linum usitatissimum) & 1 & 1 & 3 & 1 \\
\hline beans (Phaseolus vulgaris) & 3 & 1 & 0 & 0 \\
\hline squash (Cucurbita sp.) & 3 & 2 & 0 & 0 \\
\hline gourd (Lagenaria siceraria) & 0 & 0 & 1 & 3 \\
\hline cotton (Gossypium sp.) & 1 & 1 & 3 & 0 \\
\hline peppers (Capsicum sp.) & 2 & 0 & 0 & 1 \\
\hline sisal hemp (Agave americana) & 0 & 0 & 3 & 2 \\
\hline maize (Zea mays) & 2 & 3 & 0 & 0 \\
\hline mulberry (Morus sp.) & 1 & 1 & 3 & 1 \\
\hline hemp (Cannabis sativa) & 1 & 0 & 3 & 2 \\
\hline ramie (Boehmeria nivea) & 0 & 0 & 3 & 2 \\
\hline jute (Corchorus sp.) & 0 & 0 & 3 & 2 \\
\hline taro (Colocasia esculenta) & 3 & 3 & 1 & 1 \\
\hline yams (Dioscorea sp.) & 3 & 3 & 1 & 0 \\
\hline banana (Musa acuminata) & 2 & 2 & 2 & 2 \\
\hline sorghum (Sorghum bicolor) & 2 & 3 & $1^{*}$ & 0 \\
\hline \multirow{12}{*}{$\begin{array}{l}\text { animals } \\
\text { dog (Canis lupus familiaris) } \\
\text { sheep/goat (Ovis sp./ Capra sp.) } \\
\text { pig (Sus sp.) } \\
\text { llama (Lama glama) } \\
\text { fowl (Gallus gallus domesticus) } \\
\text { cattle (Bos taurus) } \\
\text { silkworm (Bombyx mori) } \\
\text { guinea pig (Cavia porcellus) } \\
\text { horse (Equus caballus) } \\
\text { camel (Camelus bactrianus) } \\
\text { cat (Felis silvestris catus) }\end{array}$} & & \multicolumn{3}{|c|}{ (commensals) } \\
\hline & 1 & (3) & 1 & 3 \\
\hline & 2 & $(0)$ & 3 & 2 \\
\hline & 1 & (3) & 0 & 2 \\
\hline & 1 & (0) & 3 & 2 \\
\hline & 3 & (3) & 1 & 1 \\
\hline & 3 & (0) & 2 & 2 \\
\hline & 0 & (0) & 3 & 1 \\
\hline & 2 & (2) & 2 & 1 \\
\hline & 1 & (0) & 1 & 3 \\
\hline & 1 & (0) & 1 & 3 \\
\hline & 0 & (3) & 1 & 3 \\
\hline \multirow{3}{*}{ totals } & 37 & 41 & 35 & 18 \\
\hline & 15 & - & 18 & 23 \\
\hline & 52 & 41 & 53 & 41 \\
\hline
\end{tabular}

products such as hemp, cotton and flax constitute the main non-comestible component, while comestibles generally included odd choices like peppers that suggest people still relied on hunting and gathering for much of their food - all which "poses a major problem for theories of domestication" (Hayden 1995:294).

Non-comestible uses of early domesticates

A fundamental but questionable assumption is that early farming was predicated on the provision of food for human consumption - seen for instance in the increasing use of the term "food production" as a synonym. What has been overlooked is the counter-intuitive possibility that, in the primary centres, food production was not a decisive factor in the formative phases of the transition to farming. Prominent among the other purposes served by the suites of early domesticates was the provision of materials for making clothes, particularly natural fibres (from plants and animals) for the weaving of textile fabrics. 


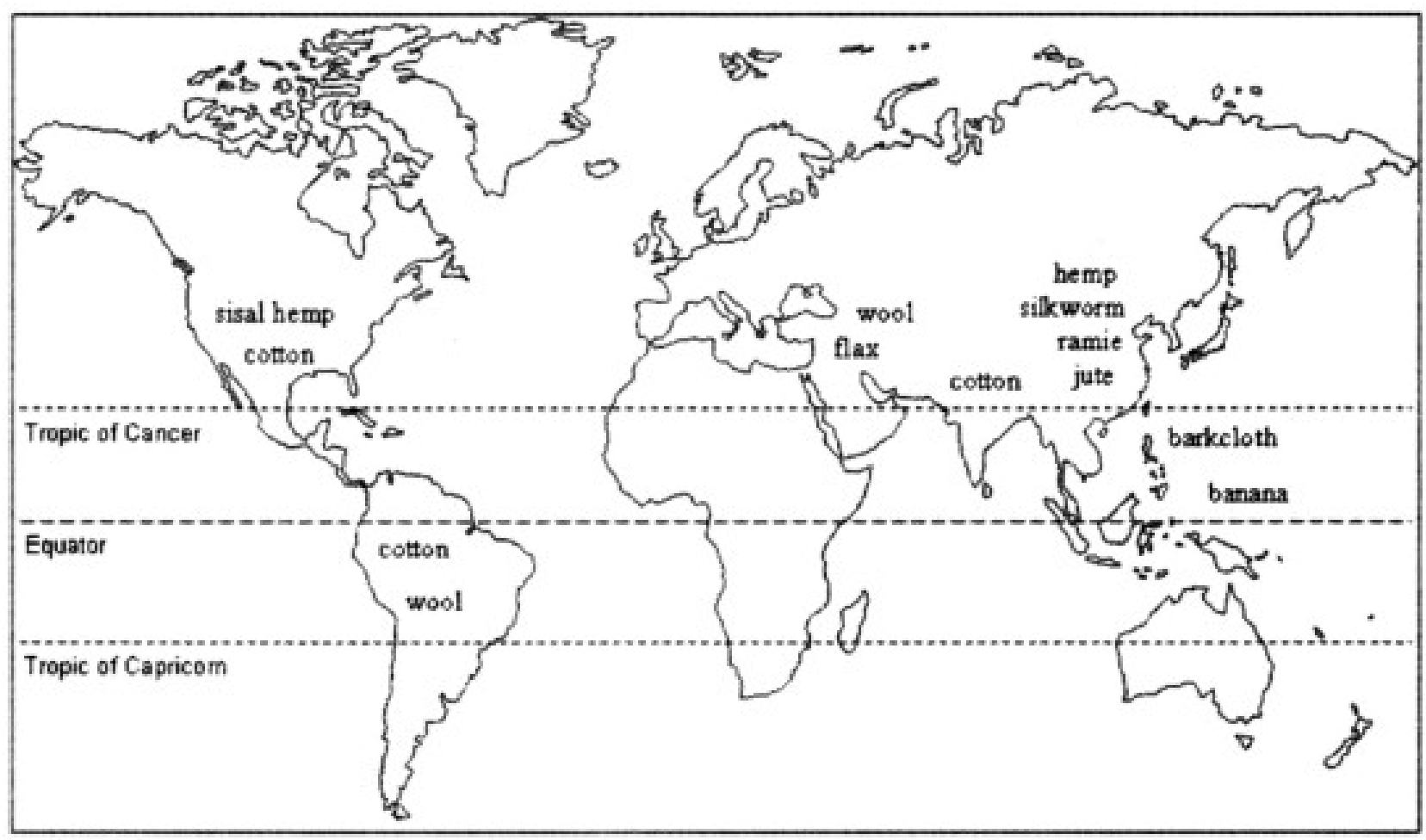

Figure 1: Early centres of domestication for major fibre resources. Barkcloth is included although it is a felted rather than woven material; while having a wide global distribution, the earliest cultivation of plants for barkcloth production occurred in Eastern (and possibly Southeast) Asia. Banana is included given its first cultivation in Papua New Guinean horticultural systems that may have arisen independently, and as an example of the multi-purpose role of many tropical plant domesticates.

Another prominent feature is that many of the plant food products were useful for feeding animals, often more so than for feeding humans. In most cases, the few plant species destined exclusively for human consumption (where they do occur) were hardly staples, especially in their wild state.

\section{THE TEXTILE PROPOSAL}

Farming only began, and subsequently was only adopted readily, in areas where humans were in the habit of wearing clothes. It began, in other words, among people whose basic needs included clothing as well as food. The regular need for substantial clothing arose during the late Pleistocene, in middle and high latitudes, and its use became habitual for various reasons (including the acquisition of personal and social purposes). The use of clothing persisted into the Holocene and, among some of these groups, farming represented a viable proposition. Where the need for clothing could be met by hunting and gathering, people favoured their traditional lifestyle over that of farming. Where there was no use of clothing, farming held no attraction and made no sense whatsoever.

\section{From furs to fibres}

In the post-glacial world, a more appropriate material than hides and furs in the warmer (and generally more humid) climates existed in the form of natural fibres.
These could be woven into cloth for garments by using pre-existing weaving technologies, employed in the manufacture of baskets, bags, mats and ropes since at least late Pleistocene times (e.g. Adovasio et al. 1996; Soffer 2004). Direct and indirect evidence for the use of textiles can be found in most if not all of the early farming centres (Figure 1).

\section{Commensals}

Another factor in many early farming contexts was the role of commensal species, particularly animal species that gravitated to human settlements, effectively domesticating themselves (Tchernov 1984; O’Connor 1997). Dogs and pigs are likely examples, and domestic fowl probably fall into this category. These species were prominent in Eastern Asia and the Pacific, and often became the primary animal domesticates in hunter-gatherer communities. The domestic dog originated in northern East Asia by 10,000 years ago (Savolainen et al. 2002) and spread widely among both farming and foraging communities; accompanying the Austronesian expansion, it reached Australia (in the form of the dingo) by 3500 years ago.

\section{Pastoralism}

The other major post-glacial lifestyle among people who wore clothes is pastoralism, where animals are domesti- 
cated but, for various reasons (usually environmental limitations), agriculture is not practised routinely. In all pastoral contexts, the production of fibres for textiles is a prominent feature. Mongolian pastoralists, for example, rely on sheep and goats for wool, meat and milk, using felted wool for their tents, and foddering the animals in winter with collected wild vegetation, mainly grasses and chenopods (Makarewicz and Tuross 2006).

\section{TEXTILES AND FODDER}

\section{China}

Foxtail millet was the main cereal crop in the Yellow River basin, dating from around 9,000 years ago, while rice predominated in the Yangtze basin, dating from the same period. Soybeans were also cultivated, perhaps a little later, and the first farm animals were pigs, dogs and fowl, with cattle appearing later. Hunting and collecting of wild foods continued throughout the formative phases of Chinese farming, and fishing contributed an important dietary component. The millet and soybeans were fed to animals as well as people and, though direct evidence is lacking, rice fields may have been fenced off because pigs and cattle would be "attracted to the growing rice" (Higham 1995:147). Like other early cereals, the wild progenitors of domesticated rice probably had relatively low food yields for humans, as has been calculated for instance with maize; assuming a similar situation with rice, these plants "would certainly not have been worth cultivating as staples" (Hayden 2003:464). Domestication of pigs dates from 8,000 years ago at the site of Cishan in the Yellow River basin, with pigs as well as humans probably consuming the cultivated millet (Jing and Flad 2002:725). Stable isotope analyses confirm that millet was used to feed both farm animals and humans (Pechenkina et al. 2005), although rice (more difficult to identify, being a C-3 food) may have dominated the human diet at the early farming site of Jiahu (Hu et al. 2006:1328).

In Eastern Asia, major fibre crops included hemp, grown mainly in the north, while those in the south included ramie and Chinese jute, useful for making ropes and fishing nets as well as clothes (Chang 1986:80). Silkworms were domesticated quite early, probably from at least 7,000 years ago in northern China, fed with leaves from cultivated mulberry trees. Carbonised fruits of hemp were found in pottery jars at Lin-chia, an early Yangshao site in northern China, while a half-cut silkworm cocoon was found at the site of Xiyincun (Chang 1986:113,143). Cordage found at Hemudu is said to be made from tough ramie fibres rather than hemp, while fabric fragments recovered at Caoxieshan, a Majiabang site in the lower Yangtze basin dating to around 7,000 years ago, may have been woven from the wild kudzu vine (Chang 1986:201). The bottle gourd was first domesticated in Asia by 10,000 years ago before spreading to the New World (Erickson et al. 2005). It serves widely as a container for fluids, but as an early function this hardly holds water: the wild varieties are very thin-walled and would not have been useful for this purpose (Erickson et al. 2005). Given their soft fibrous covering, they may have been exploited initially as bags or even as a resource for clothing-related materials, either for the fibres or as barkcloth.

\section{Japan}

Hemp, which yields oil and food as well as fibre, was grown in the Southeast Asian and Japanese farming contexts (An 1989:647). In Japan, archaeological evidence exists for hemp and paper mulberry at the site of Hamanasuno, belonging to the early Jomon period (7,200-5,600 years ago), and hemp has been identified in early Jomon levels at Torihama in southwestern Japan (Crawford 1992:27-29; Higham 1995:142). Within this huntergatherer context, a variety of plant species were gradually brought under cultivation during the middle and late Jomon. Spindle whorls and crops such as barley, buckwheat, hemp, beans, various spices and millet species (barnyard, broomcorn and, later, foxtail) are documented from sites in northern Honshu and on Hokkaido, where the Ainu continued as sedentary foragers and part-time farmers into historical times (Crawford and Takamiya 1990:898; D’Andrea 1995; Kuzmin et al. 1998a:814; Fitzhugh and Dubreuil 1999). Besides fibre products, most of the likely cultivars by middle Jomon times around 4,000 years ago were herbs and spices rather than food staples, which "presents a major problem in the debate over Jomon agriculture" (Imamura 1996:108). Textile fragments and parts of wooden looms have survived from the succeeding Yayoi period at water-logged sites such as Toro, $150 \mathrm{~km}$ southwest of Tokyo (Aikens and Higuchi 1982:226-237), associated with the transition to full-scale farming around 2,500 years ago.

\section{Russian Far East}

From the terminal Pleistocene through to the midHolocene, communities in the Far East of Russia and around the Sea of Japan continued as hunter-gatherers, generally on a semi-sedentary or fully sedentary basis, with the advent of pottery rather than farming defining the Early Neolithic cultural phase. A number of large hidebearing animal species such as mammoth, horse, and bison disappeared as temperatures rose and forest cover increased, with the earliest domesticated animals (pig and dog) appearing late, around 3,000 years ago, possibly from northern China (Kuzmin 1997:176-177; Kononenko and Kajiwara 2003:144). Agriculture based on the cultivation of foxtail millet begins between 4000 and 5000 years ago, having spread northwards from its Chinese core area (Kuzmin et al. 1998a:815). Spindle whorls attest to the weaving of textiles at many Early Neolithic sites, presumably using wild plant fibres, with fragments of woven fabric surviving at Chertovy Vorota, a cave in the Primorye region (Kononenko 1991:94-95; Kononenko $2005: 157)$. This site is dated to between 6,000 and 7,000 years ago, the warmest phase of the Holocene (Kuzmin 1997:173; Kuzmin et al. 1998b:677), and stable isotope analysis of human bone remains indicate a mixed foraging economy, based possibly on terrestrial mammal hunting, nut gathering and salmon fishing (Kuzmin et al. 2002:56). 
Further direct dating of the textiles could yield an even earlier date for these woven fibres, which may derive from local wild nettles (Kuzmin, pers. comm. September 2006).

\section{Korea and Taiwan}

Evidence for textiles in the form of clay spindle whorls dates from 5,000 years ago in Korea and Taiwan, as farming spread into these regions from China (Kim 1978:7-52; Nelson 1993:159; Bellwood 1997:215). Early weaving throughout Eastern Asia is confirmed by spindle whorls and the typical cord and basketry impressions left on pottery. The raw material used in the cords is not identified, although the strong fibres of hemp are a prime candidate. Given that wild foodstuffs were always abundant throughout Eastern Asia, Chang once wondered whether food crops may have played only a "minor role" in the oriental transition to farming (Chang 1970:180). Subsequent research has added much detail to the picture, but Chang's observation remains valid. Carl Sauer was similarly sceptical, noting the "curious" choice of domesticates (Sauer 1969:88-90). He observed that some early crops served other purposes, "especially as sources of fiber", and suggested that food was "perhaps not the most important reason for bringing plants under cultivation" (Sauer 1969:27,115).

\section{Papua New Guinea}

The cultivation of taro, yams and bananas by 7,000 years ago in the highlands of Papua New Guinea (Denham 2003; Fullagar et al. 2006) is said to elevate this region to the status of a "primary centre" of early farming (Denham et al. 2003:192). Horticultural systems of land use (combined with hunting and gathering) may date to the beginning of the Holocene in Melanesia, if not earlier (Spriggs 1996), and predate the intrusion of fully agricultural systems from island Southeast Asia around 3500 years ago (Denham and Barton 2006).

Bananas were first domesticated in this area, and phytolith evidence for domesticated bananas (derived from Papua New Guinea) appears as far afield as the highlands of Uganda, possibly by 5000 years ago (Lejju et al. 2006). Virtually all tropical domesticates are multipurpose resources (Thamon et al. 2000; Kennedy and Clarke 2004) and were not necessarily important in the human diet initially, particularly in their wild state. Bananas are a prime example: most wild forms are neither particularly palatable nor edible, being full of large indigestible seeds, with the prominent sweet pulp of modern seedless varieties a result of domestication. Fibres from banana plants are useful for many purposes, including the weaving of nets and ropes as well as cloth for clothing. A major commercial fibre, abacá or "Manila hemp", is extracted from a species of banana (Musa textilis) native to the Philippines. Bananas, along with the root crops in general, also make excellent feed for animals, especially pigs (Cliff 1993:115). In Papua New Guinea, a substantial proportion of the crop was often fed to pigs, with the latter having only a minor contribution the human diet (Rappaport 1984).

The clothing worn in central Papua New Guinea at first European contact was rudimentary but, unlike their neighbours to the south in Australia, people were not habitually unclad. Small aprons or skirts made from woven cords, netting or barkcloth served as pubic and rear coverings, manufactured from leaves, grass, ferns or bark from various trees (Brown 1978:48-49). Males often wore only a penis gourd held in place by a string around the hips; some groups made simple cloaks from barkcloth and women also made string bags or bilums from hand-spun bark fibres (Craig 1988:14-17).

The question arises as to whether people used more clothing in the past, especially during the Last Glacial Maximum (LGM). While lying close to the equator, the highland valleys enjoy a comparatively mild climate due to their elevation (around $1500-2500 \mathrm{~m}$ ), and humans were present in the area during the LGM (White and O'Connell 1982:56-59). At Goroka weather station (1587m), minimum temperatures today are $12-14^{\circ} \mathrm{C}$. Mean temperatures during the LGM fell by $4-7^{\circ} \mathrm{C}$ (Hope and Golson 1995:820), suggesting minimum air temperatures then in the range $5-10^{\circ} \mathrm{C}$. As with their Australian Aboriginal counterparts who occupied the remainder of Sahul during the last glaciation, the time depth of human occupation in this region results in the indigenous peoples becoming physically adapted to their local climate (Gilligan and Bulbeck in press). In northern parts they are adapted to warmer conditions, and in the highlands may have needed clothing during the LGM. The abundance of wild plant fibre resources would favour an early (and probably independent) development of textile and related cloth-making technologies, suitable as materials for clothing in the humid tropics.

\section{The Indus Valley}

Early farming in this region was influenced strongly by external developments. Sheep, goats and wheat had spread eastwards from Mesopotamia, while rice and silkworms had spread westwards from Eastern Asia. A number of plant and animal species were first domesticated in this region, including humped cattle (Bradley and Magee 2006:325) and the earliest Old World cotton, cultivated well before the rise of Harappan civilisation, probably by around 6500 years ago (Meadow 1996:396). Most clothing on the hot Indian subcontinent comprised looselydraped cotton garments; cotton subsequently spread westwards through Arabia by 5500 years ago (Betts et al 1994) and thence to Egypt. Cotton also spread to Southeast Asia, which absorbed clothing influences from India as well as China, especially with the arrival of Hinduism and Buddhism after 2000 years ago. Clothing standards were also influenced in parts of Southeast Asia by the spread of Islam after 1,200 years ago, which carried rice westwards into the Mediterranean region (Glover\& Higham 1996). 


\section{Barkcloth}

Clothing in Eastern Asia (and throughout island Southeast Asia and the Pacific) was made from barkcloth as well as textiles. The main source of bark was the paper mulberry tree, indigenous to Eastern Asia where barkcloth technology may have originated (Aragon 1990:36-44), although breadfruit, Manila hemp and fig trees were also sources in many areas. In Polynesia, sheets of tapa could be sewn together, and sometimes multiple layers were used to make sleeping bags (Kooijman 1988). The prehistory of barkcloth is poorly documented, due to the perishability of wooden beaters and of the fragile cloth itself, which is a kind of paper that begins to disintegrate in the rain. Stone beaters survive in Taiwan, the Philippines and Indonesia dating to between 6,000 and 2,000 years ago (Bellwood 1997:212-227).

\section{Failure to develop farming}

The Indo-Pacific region provides two examples of a total failure to develop farming: the Australian Aborigines and the Andaman Islanders. The "total absence" of farming developments anywhere in Australia is "very striking" (Bellwood 1996:487). So too was the habitual nakedness of Australian Aborigines to the first Europeans who made contact with them. There was some casual use of garments for protection from the cold in the southern areas, but clothing was not used regularly for social or other purposes; the only exceptions occurred on the northern fringes, and are attributable to external influence (Gilligan In press). The indigenous inhabitants of the Andaman Islands were likewise habitually naked, and they remained surprisingly unaffected by the farming and other developments that occurred in nearby regions throughout most of the Holocene. They displayed indifference to the trappings of civilisation and resistance to the adoption of farming practices, despite the efforts of missionaries and, more recently, government officials (Mukerjee 2003).

\section{THE INSULAR MODEL}

To summarise (and simplify) the picture, farming arose in those areas where two of the main post-glacial trends coincided, both of which can be related to repercussions of clothing. The trends are sedentism and resource domestication (Table 2), and farming occurs in the zone where they intersect.

\section{Sedentism}

The factors leading to sedentism remain poorly understood (e.g., Rosenberg 1998; Hayden 2000). Whatever its proximate causes, the development and elaboration of permanent settlements reflects a distinct alteration of human attitudes to the natural world. It reflects a withdrawal or detachment of humans from wide-ranging contacts with their natural physical surroundings (and equally, attachment to an artificial, fabricated environment, beginning with clothing). In this respect, sedentism is an outer manifestation of the inner separation of humans from their surroundings that clothing engenders. It implies "domes- tication" of humans themselves and their physical envi ronment, as seen among many hunter-gatherer communities in mainland Southeast Asia where clothing was used prior to the dispersal of farming:

The contrast can be summarized in the word domestication. Sedentism at its simplest level...indicates... domestication not necessarily of plants and animals, but rather of people... In this context, it is immaterial whether the plants found there were cultivated or not, or whether animal behaviour was yet modified by people to the point of herd maintenance (Higham \& Maloney 1989:662).

One possible archaeological correlate of increasing sedentism is production of ceramic artefacts (e.g. Hayden 1993:233). The world's first pottery appears in Eastern Asia, in hunter-gatherer contexts during the terminal Pleistocene, with three independent centres dating to around 14,000-13,000 years ago - southern China, the Russian Far East, and Japan (Kuzmin 2006).

Table 2. Early farming as a product of two post-glacial trends.

SEDENTISM

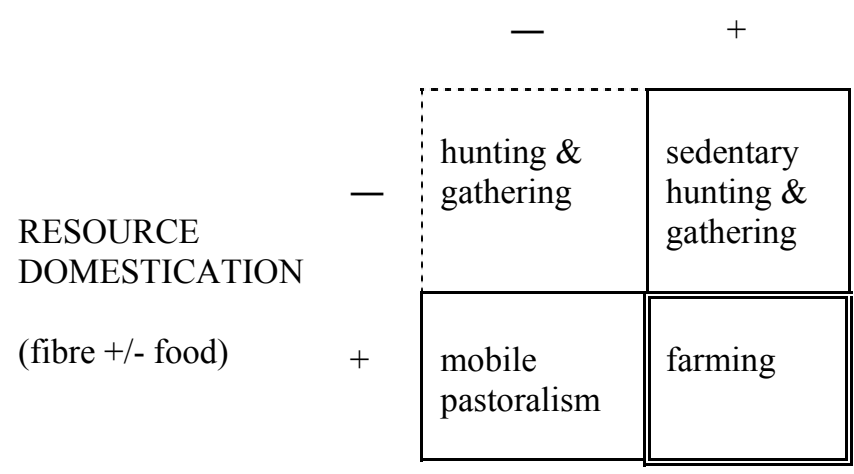

\section{Population growth}

Population growth is not readily attributable to the availability of a food surplus - more food does not create more babies, only fatter ones. Even endemic malnutrition has little impact on maternal fertility, and high infant mortality rates are readily offset by higher birth rates, as Third World famines demonstrate only too clearly. Population growth among early farmers probably resulted from reduced birth spacing, in contrast to the prolonged birth spacing witnessed among hunter-gatherer populations. Breastfeeding acts hormonally as a contraceptive, leading to greater birth spacing (Howie and McNeilly 1982). The question is why breastfeeding might be reduced in early farming contexts.

Availability of milk products and substitutes from farm animals and crops was a factor in some areas, but in itself does not necessarily answer the question of why breastfeeding should decline. Habitual use of clothing may have contributed for a number of reasons, for instance by encouraging modesty and affecting cultural attitudes to breastfeeding. Isotopic analyses of infant skeletal remains are consistent with an early onset of 
weaning in agricultural communities (e.g. Williams et al. 2005; Fuller et al. 2006). While ecological constraints have been posited as the reason for late weaning among foraging populations such as the !Kung, isotopic analyses of their mid-Holocene ancestors (whose environmental circumstances were decidedly more favourable) indicate similar weaning practices, suggesting that "cultural" factors are involved (Clayton et al. 2006).

Like sedentism, human population growth (or the collapse of pre-existing controls) is a prominent though not universal trend of the late Pleistocene and early Holocene. Theoretical perspectives must accommodate spatial and temporal variations in population size that run counter to the main trends. Although considered archaeologically invisible, the development of clothing during the late Pleistocene may provide a useful dimension within which to explore these varying local and general population trends.

\section{Food production and urbanisation}

The present model relates only to the initial, de novo advent of farming practices in a hunter-gatherer context. Here most of the crops provided fibres for textiles or fodder for animals that themselves either provided fibres or (like pigs and dogs) were commensals. Any need for a food surplus was not so much to feed an expanding human population (although this became increasingly relevant), but because early farmers were often feeding animals as well as themselves. The conventional view is inverted, with food crops for human consumption (along with animals first domesticated mainly for food, such as cattle) being more a secondary product (e.g. for condiments and feasting), with staple foods provided by hunting and gathering. Once farming settlements became viable, a shift to full-scale food production for humans was favoured for many reasons, including co-evolutionary effects between humans and their domesticates (Rindos 1984), as well as diminishing returns from hunting and gathering, population growth, and increasing social complexity. The next step, dependence on farming to feed people, was crucial. Humans then met all their basic resource needs - for both food and clothing — outside the natural environment, within the artificial environment of the farming community. This culminated in urbanisation, where people exist in a humanly-manipulated world and live largely apart from unmodified nature.

\section{HUMAN DOMESTICATION}

In both a pragmatic and perceptual sense, farming reflects a basic alteration in human relationships - environmental relationships, social relationships and, at the most fundamental level, psychological relationships to physical, bodily existence. Humans who wear clothes habitually come to perceive themselves and their world differently, and their world becomes different as a result. The significance of farming is that it provided the practical means by which this inner transformation became manifest in a series of external transformations. What these have in common is that they all function, directly and indirectly, to reify and intensify an insular mode of existence. In the early urban environments, the various interlaced systems are essentially "insular" and self-promoting (Renfrew 1972:11-16). As Hodder suggests, farming is a way for humans to domesticate the "external" world of nature, a "bringing in" of the wild to make it comfortable and safe for people who have become alienated from the wilderness outside (Hodder 1990:12-18; see also Whittle 1996:370). This insular existence is preferred by clothed people and has its origins in the acquisition and habitual use of clothing.

At a biological level, clothing alters direct sensory awareness of, and contact with, the physical environment. The insular world, created through sedentism and especially farming, is a kind of external clothing. Modified landscapes and fabricated structures protect its denizens from exposure to environmental fluctuations, thus reducing contact with (and awareness of) the full range of natural stimuli that otherwise impinge on the uncovered skin surface. Those that live within this world - both humans and their domesticated animals - become insulated, whether or not they wear clothing (and, in the case of modern-day humans, accustomed to a plethora of alternative - especially non-tactile — stimuli). This is at the core of the domestication process, a decline in perception or "appreciation" of the natural environment (Hemmer 1990), and it applies to humans as well as domesticated animals (Groves 1999; Leach 2003). Technically, it applies even to cultivated plants, although the process in that case is entirely biological rather than partly behavioural.

\section{CONCLUSION}

Numerous strands of evidence raise doubts as to whether the early development of farming was related to the production of food for human consumption. Conversely, much evidence points to the role of non-comestible products and also to the use of food crops in feeding domesticated animals. Beyond the Indo-Pacific region, a similar pattern is discernible in all the other farming centres. Production of fibres for textile clothing from both plant and animal domesticates is a prominent feature. It is suggested that this aspect, in conjunction with other trends that may relate to repercussions of clothing, provides an alternative rationale for the transition to farming in the post-glacial world.

\section{ACKNOWLEDGEMENTS}

This paper derives from a presentation at the 2006 IPPA conference in Manila. The author thanks Peter Bellwood, Secretary-General of IPPA, and Peter Lape, convenor of the Climate Change session, for their support and encouragement. It was also inspired by Bellwood's recent book First Farmers, which offers a refreshing perspective on the subject. Peter Bellwood, Colin Groves, Brian Hayden and Peter White kindly read earlier drafts. The present paper has benefited greatly from their critical comments and those of two anonymous reviewers. 


\section{REFERENCES}

Adovasio, J.M., Soffer, O., and Klíma, B. 1996. Upper palaeolithic fibre technology: interlaced woven finds from Pavlov I, Czech Republic, c. 26,000 years ago. Antiquity 70:526-534.

Aikens, C.M., and Higuchi, T. 1982. Prehistory of Japan. New York: Academic Press.

An, Z. 1989. Prehistoric agriculture in China. In D.R. Harris and G.C. Hillman (eds), Foraging and Farming: The Evolution of Plant Exploitation, pp. 642-649. London: Unwin Hyman.

Aragon, L.V. 1990. Barkcloth production in central Sulawesi. Expedition 32(1):33-48.

Bellwood, P. 1996. The origins and spread of agriculture in the Indo-Pacific region: gradualism and diffusion or revolution and colonization? In D.R. Harris (ed), The Origins and Spread of Agriculture and Pastoralism in Eurasia, pp. 465-498. London: UCL Press.

Bellwood, P. 1997. Prehistory of the Indo-Malaysian Archipelago. Revised edition. Honolulu, HI: University of Hawai'i Press.

Bellwood, P. 2005. First Farmers: The Origins of Agricultural Societies. Oxford: Blackwell.

Benyshek, D.C. and Watson, J.T. 2006. Exploring the thrifty genotype's food-shortage assumptions: a cross-cultural comparison of ethnographic accounts of food security among foraging and agricultural societies. American Journal of Physical Anthropology 131:120-126.

Betts, A., van der Borg, K., de Jong, A., McClintock, C. and van Strydonck, M. 1994. Early cotton in north Arabia. Journal of Archaeological Science 21:489-499.

Bradley, D.G. and Magee, D.A. 2006. Genetics and the origins of domestic cattle. In M.A. Zeder, D.G. Bradley, E. Emshwiller and B.D. Smith (eds), Documenting Domestication: New Genetic and Archaeological Paradigms, pp. 317-328. Berkeley: University of California Press.

Brown, P. 1978. Highland Peoples of New Guinea. Cambridge: Cambridge University Press.

Chang, K.C. 1970. The beginnings of agriculture in the Far East. Antiquity 40:175-185.

Chang, K.C. 1986. The Archaeology of Ancient China. Fourth edition. New Haven, CT: Yale University Press.

Clayton, F., Sealy, J. and Pfeiffer, S. 2006. Weaning age among foragers at Matjes River Rock Shelter, South Africa, from stable nitrogen and carbon isotope analyses. American Journal of Physical Anthropology 129:311-317.

Cliff, A. 1993. Farm Animals for Gardens and Backyards. Melbourne: Aird.

Craig, B. 1988. Art and Decoration of Central New Guinea. Aylesbury: Shire Publications.

Crawford, G.W. 1992. Prehistoric plant domestication in east Asia. In C.W. Cowan and P.J. Watson (eds), The Origins of Agriculture: An International Perspective, pp. 7-38. Washington, DC: Smithsonian Institution.

Crawford, G.W. and Takamiya, H. 1990. The origins and implications of late prehistoric plant husbandry in northern Japan. Antiquity 64:889-911.

D'Andrea, A.C. 1995. Later Jomon subsistence in northeastern Japan: new evidence from palaeoethnobotanical remains. Asian Perspectives 34:195-227.
Denham, T. 2003. Archaeological evidence for mid-Holocene agriculture in the interior of Papua New Guinea: a critical review. Archaeology in Oceania 38:159-185.

Denham, T. and Barton, H. 2006. The emergence of agriculture in New Guinea. In D.J. Kennett and B. Winterhalder (eds), Behavioral Ecology and the Transition to Agriculture, 237-264. Berkeley: University of California Press.

Erickson, D.L., Smith, B.D., Clarke, A.C., Sandweiss, D.H. and Tuross, N. 2005. An Asian origin for a 10,000-year-old domesticated plant in the Americas. Proceedings of the National Academy of Sciences of the United States of America 102:18315-18320.

Fitzhugh, W.W. and Dubreuil, C.O. (eds). 1999. Ainu: Spirit of a Northern People. Washington, DC: Smithsonian Institution / University of Washington Press.

Flannery, K.V. (ed). 1986. Guilá Naquitz: Archaic Foraging and Early Agriculture in Oaxaca, Mexico. New York, NY: Academic Press.

Fullagar, R., Field, J., Denham, T. and Lentfer, C. 2006. Early and mid Holocene tool-use and processing of taro (Colocasia esculenta), yam (Dioscorea sp.) and other plants at Kuk Swamp in the highlands of Papua New Guinea. Journal of Archaeological Science 33:595-614.

Fuller, B.T., Molleson, T.I., Harris, D.A., Gilmour, L.T. and Hedges, R.E.M. 2006. Isotopic evidence for breastfeeding and possible adult dietary differences from late/subRoman Britain. American Journal of Physical Anthropology 129:45-54.

Gentry, A., Clutton-Brock, J. and Groves, C.P. 2004. The naming of wild animal species and their domestic derivatives. Journal of Archaeological Science 31:645-651.

Gilligan, I.J. In press. Another Tasmanian Paradox: Clothing and Thermal Adaptations in Aboriginal Australia. BAR International Series. Oxford: Archaeopress.

Gilligan, I.J. and Bulbeck, D. In press. Environment and morphology in Australian Aborigines: a re-analysis of the Birdsell database. American Journal of Physical Anthropology.

Glover, I.C. and Higham, C.F.W. 1996. New evidence for early rice cultivation in South, Southeast and East Asia. In D.R. Harris (ed), The Origins and Spread of Agriculture and Pastoralism in Eurasia, pp. 413-441. London: UCL Press.

Groves, C.P. 1999. The advantages and disadvantages of being domesticated. Perspectives in Human Biology 4:1-12.

Hayden, B. 1990. Nimrods, piscators, pluckers, and planters: the emergence of food production. Journal of Anthropological Archaeology 9:31-69.

Hayden, B. 1993. Archaeology: The Science of Once and Future Things. New York: W.H. Freeman.

Hayden, B. 1995. A new overview of domestication. In T.D. Price and A.B. Gebauer (eds), Last Hunters - First Farmers: New Perspectives on the Prehistoric Transition to Agriculture, pp. 273-299. Santa Fe, NM: School of American Research.

Hayden, B. 2000. On territoriality and sedentism. Current Anthropology 41:109-112.

Hayden, B. 2003. Were luxury goods the first domesticates? Ethnoarchaeological perspectives from Southeast Asia. World Archaeology 34:458-469. 
Hemmer, H. 1990. Domestication: The Decline of Environmental Appreciation. Cambridge: Cambridge University Press.

Higham, C.F.W. and Maloney, B. 1989. Coastal adaptation, sedentism, and domestication: intensification in prehistoric Southeast Asia. In D.R. Harris G.C. Hillman (eds), Foraging and Farming: The Evolution of Plant Exploitation, pp. 650-666. London: Unwin Hyman.

Hodder, I. 1990. The Domestication of Europe: Structure and Contingency in Neolithic Societies. Oxford: Blackwell.

Hope, G. and Golson, J. 1995. Late Quaternary change in the mountains of New Guinea. Antiquity 69:818-830.

Howie, P.W. and McNeilly, A.S. 1982. Effects of breastfeeding patterns on human birth intervals. Journal of Reproduction and Fertility 65:545-557.

$\mathrm{Hu}$, Y., Ambrose, S.H. and Wang, C. 2006. Stable isotopic analysis of human bones from Jiahu site, Henan, China: implications for the transition to agriculture. Journal of Archaeological Science 33:1319-1330.

Imamura, K. 1996. Prehistoric Japan: New Perspectives on Insular East Asia. London: UCL Press.

Ingold, T. 1984. Time, social relationships and the exploitation of animals: anthropological reflections on prehistory. In J. Clutton-Brock and C. Grigson (eds), Animals and Archaeology: 3. Early Herders and Their Flocks, pp. 3-12. Oxford: BAR International Series 202.

Jing, Y. and Flad, R.K. 2002. Pig domestication in ancient China. Antiquity 76:724-732.

Keeley, L.H. 1995. Protoagricultural practices among huntergatherers: a cross-cultural survey. In T.D. Price and A.B. Gebauer (eds), Last Hunters - First Farmers: New Perspectives on the Prehistoric Transition to Agriculture, pp. 243-272. Santa Fe: School of American Research.

Kennedy, J. and Clarke, W. 2004. Cultivated Landscapes of the Southwest Pacific. Canberra: Resource Management in Asia-Pacific Program, Research School of Pacific and Asian Studies, Australian National University.

Kim, J-H. 1978. The Prehistory of Korea. Honolulu, HI: University Press of Hawaii.

Kononenko, N.A. 1991. Samples from bone, horn, wood and textile. In G.V. Andreeva (ed), The Neolithic of the Southern Far East (Ancient Site in the Chertovy Vorota Cave), pp. 81-96. Moscow: Nauka.

Kononenko, N.A. 2005. The transition from hunter-gatherer subsistence practices to the marine resource exploitation in the Russian Far East. In N.A. Goraychev, E.M. Kokorev and U.I. Mumortsev (eds), North Pacific: Cultural Adaptations at the End of the Pleistocene and Holocene, pp. 154-158. Magadan: Northern International University.

Kononenko, N.A. and Kajiwara, H. 2003. Chronology and ecology of archaeological sites of late-Pleistocene - early Holocene in the Zerkalnaya River valley. In A.P. Derevianko and N.A. Kononenko (eds), Foraging Population of the Sea of Japan during the Late Pleistocene - Early Holocene, pp. 140-146. Novosibirsk: Russian Academy of Sciences/Tohoku Fukushi University.

Kooijman, S. 1988. Polynesian Barkcloth. Aylesbury: Shire.

Kuzmin, Y.V. 1997. Vertebrate animal remains from prehistoric and medieval settlements in Primorye (Russian Far East). International Journal of Osteoarchaeology 7:172-180.
Kuzmin, Y.V. 2006. Chronology of the earliest pottery in East Asia: progress and pitfalls. Antiquity 80:362-371.

Kuzmin, Y.V., Jull, A.J.T., and Jones, G.A. 1998a. Early agriculture in Primorye, Russian Far East: New radiocarbon and pollen data from Late Neolithic sites. Journal of Archaeological Science 25:813-816.

Kuzmin, Y.V., Jull, A.J.T., Orlova, L.A., and Sulerzhitsky, L.D. 1998b. 14C chronology of Stone Age cultures in the Russian Far East. Radiocarbon 40:675-686.

Kuzmin, Y.V., Richards, M.P., and Yoneda, M. 2002. Palaeodietary patterning and radiocarbon dating of neolithic populations in the Primorye Province, Russian Far East. Ancient Biomolecules 4:53-58.

Larsen, C.S. 2006. The agricultural revolution as environmental catastrophe: implications for health and lifestyle in the Holocene. Quaternary International 150:12-20.

Leach, H.M. 2003. Human domestication reconsidered. Current Anthropology 44:349-368.

Lejju, B.J., Robertshaw, P. and Taylor, D. 2006. Africa's earliest bananas? Journal of Archaeological Science 33:102113

Makarewicz, C. and Tuross, N. 2006. Foddering by Mongolian pastoralists is recorded in the stable carbon $(\delta 13 \mathrm{C})$ and nitrogen $(\delta 15 \mathrm{~N})$ isotopes of caprine dentinal collagen. Journal of Archaeological Science 33:862-870.

Meadow, R.H. 1996. The origins and spread of agriculture and pastoralism in northwestern South Asia. In D.R. Harris (ed), The Origins and Spread of Agriculture and Pastoralism in Eurasia, pp. 390-412. London: UCL Press.

Mukerjee, M. 2003. The Land of Naked People: Encouners with Stone Age Islanders. New York, NY: Houghton Mifflin.

Nelson, S.M. 1993. The Archaeology of Korea. Cambridge: Cambridge University Press.

O'Connor, T.P. 1997. Working at relationships: another look at animal domestication. Antiquity 71:149-156.

Pechenkina, E.A., Ambrose, S.H., Xiaolin, M. and Benfer, R.A. Jr. 2005. Reconstructing northern Chinese neolithic subsistence practices by isotopic analysis. Journal of Archaeological Science 32:1176-1189.

Rappaport, R.A. 1984. Pigs for the ancestors: ritual in the ecology of a New Guinea people. New Haven, CT: Yale University Press.

Renfrew, C. 1972. The Emergence of Civilisation: The Cyclades and the Aegean in the Third Millenium B.C. London: Methuen.

Rindos, D. 1984. The Origins of Agriculture: An Evolutionary Perspective. Orlando, FL: Academic Press.

Rosenberg, M. 1998. Cheating at musical chairs: territoriality and sedentism in an evolutionary context. Current Anthropology 39:653-681.

Sauer, C.O. 1969. Agricultural Origins and Dispersals: The Domestication of Animals and Foodstuffs. Second edition. Cambridge, MA: M.I.T. Press.

Savolainen, P., Zhang, Y-p., Luo, J., Lundeberg, J. and Leitner, T. 2002. Genetic evidence for an East Asian origin of domestic dogs. Science 298:1610-1613.

Smith, B.D. 1995. The Emergence of Agriculture. New York: W.H. Freeman/Scientific American.

Soffer, O. 2004. Recovering perishable technologies through use wear on tools: preliminary evidence for upper paleolithic 
weaving and net making. Current Anthropology 45: 407425.

Spriggs, M. 1996. Early agriculture and what went on before in Island Melanesia: continuity or intrusion? In D. Harris (ed.), The Origins and Spread of Agriculture and Pastoralism in Eurasia, pp. 524-537. London: UCL Press.

Tchernov, E. 1984. Commensal animals and human sedentism in the Middle East. In J. Clutton-Brock and C. Grigson (eds), Animals and Archaeology: 3. Early Herders and Their Flocks, pp. 91-115. Oxford: BAR International Series 202.

Thamon, R.R., Elevitch, C.R. and Wilkinson, K.M. 2000. Multipurpose Trees for Agroforestry in the Pacific Islands. Holualoa, HI: Permanent Agriculture Resources.

White, J.P. and O'Connell, J.F. 1982. A Prehistory of Australia, New Guinea and Sahul. Sydney: Academic Press.
Whittle, A. 1996. Europe in the Neolithic: The Creation of New Worlds. Cambridge: Cambridge University Press.

Williams, J.S., White, C.D. and Longstaffe, F.J. 2005. Trophic level and macronutrient shift effects associated with the weaning process in the Postclassic Maya. American Journal of Physical Anthropology 128:781-790.

Winterhalder, B. and Kennett, D.J. 2006. Behavioral ecology and the transition from hunting and gathering to agriculture. In D.J. Kennett and B. Winterhalder (eds), Behavioral Ecology and the Transition to Agriculture, 1-21. Berkeley: University of California Press.

Zeder, M.A. 2006. Central questions in the domestication of plants and animals. Evolutionary Anthropology 15:105117. 